\title{
Shifting Capitalist Critiques: The Discourse about Unionisation in the Hi-Tech Sector
}

\author{
Eran Fisher* and Ben Fisher** \\ *The Open University, Ra'anana, Israel, eranfisher@gmail.com \\ **Independent scholar, Berlin, Germany, fisher.ben.1983@gmail.com
}

\begin{abstract}
Drawing on Luc Boltanski's work on capitalist transformations we argue that recent hi-tech unionising features a new model of critique which combines tenets from both the social and the artistic critique. Hi-tech workers - cultured in the ethos and achievements of the artistic critique that protests the inhibition of creativity, and the lack of personal expression and authenticity prevalent in capitalism - seek to resurrect the social critique that protests the inequality, poverty, and egoism that capitalism entails. This creates an interesting dynamic of protest discourse since the social critique partly stands in contradiction to the artistic critique: responding to one entails ignoring the other. The analysis of interviews with leaders of unionisation efforts in global hi-tech firms elucidates the tension between the two clusters of critique and the attempts to overcome it. It also allows us to engage theoretically with Boltanski by highlighting the particular characteristics of the agents voicing the critique.
\end{abstract}

Keywords: capitalism, critique, unionisation, high-tech sector, hi-tech sector, Luc Boltanski

\section{Introduction}

Research into the world of work in contemporary capitalism has recently paid attention predominantly to the most radical transformations, those that diverge most acutely and evidently from the Fordist model of employment. Under the general heading of the gig economy, sharing economy, platform capitalism and many more, there has been a tremendous amount of theoretical and empirical work that seeks to make sociological sense of new modes of employment and work schemes epitomised by Uber, Fivver, Mechanical Turk, and many more. All these do indeed capture the novelty that emerges at the intersection of new media technology and transformations in capitalism. But in this important prism, one line of enquiry seems to be overlooked, particularly by critical scholarship geared towards social change: transformations in the more traditional world of work, where relatively stable employment schemes are still in place, but where new media technology is a central protagonist; that is, in hightechnology firms. Unlike so many cases in platform/gig/sharing economy case studies, workers at the top echelon of the hi-tech industry retain some of the leverages of the Fordist era: they are highly skilled, enjoy a relatively long-term full employment, are highly paid, and often work in a shared space with colleagues (allowing communication and organisation), to name a few. They also carry much of what characterises contemporary work life: high flexibility, overwork, and receptivity to a much more competitive environment, even within their own organisation. To understand the ideological undercurrents of contemporary capitalism and its new world of work, it is therefore crucial to examine transformations of not only the most vulnerable and overexploited (growing) margins of capitalism, but to look at transformations occurring at its very heart: the hi-tech industry. That is the task of this article. 
In the last decades, the elite of hi-tech workers - programmers, engineers, designers, and so forth - have been an antinomy to unions. In the most neoliberal economies, unionisation rates have gone down dramatically (Preminger 2018; Schiavone 2008), being almost absent in the hi-tech sector. This phenomenon can be explained structurally, ideologically, and materially. Structurally, the hi-tech sector has been the crown jewel of a neoliberal labour market characterised by personal employment contracts, high workforce mobility, and unstable career paths. What's more, after a few decades of neoliberalism, hi-tech workers, standing at the forefront of digital capitalism, seem to subscribe to an ideology which rejects the very raison d'être of unions, instead upholding radical meritocratic, individualistic, free market principles. Materially, it is precisely these workers that gained most, as a class, from the restructuring of the labour market along neoliberal lines.

The last few years, however, have witnessed a resurgence of unionising efforts in general, and more importantly, a new effort for unionising in the hi-tech industry. This also represents a more general effort for organising and unionising in the media and technology sectors (de Peuter and Cohen 2015). In Israel, which serves as a case study for our research, unionising efforts in the hi-tech sector, which have hitherto been completely absent, took place in seven major firms. This tidal change could be explained as a result of a crawling proletarisation of hi-tech workers and their accelerated entry into the precarious class (Fisher and Fisher 2019a).

What interests us here, though, is not why we now see a renewal of unionising among hi-tech workers, but rather how they do that at the ideological level; particularly, how they negotiate an ethos of meritocracy, personal expression and flexibility with new demands for social security, mutual commitment, and job stability. In sum, we seek to lay bare how hi-tech unionisers articulate their critique of their employment terms, seeing that as a concrete case of the critique of contemporary capitalism. To do that we engage Luc Boltanski's sociology of critique.

Boltanski theorises capitalism by historicising its critique. What is left outside the analysis are transformations of the subjectivities that articulate critique; subjectivities which are themselves historical and derive inter alia from transformations in the experiences of working life. In this article we show how the contemporary critique of capitalism is shaped by the changing complexities of working life. Capitalist critique is not merely an intellectual-cognitive activity but is intertwined with the real-life experiences of the agents articulating it and fighting to voice it. Following Boltanski's theoretical model we argue that the discourse about unions among hi-tech workers in Israel puts forth a new model of the critique of network capitalism that draws on existing models of critique - the social and the artistic - but also creates a new synthesis. To understand the dynamics underlying this new form of critique we need to be attentive to the particular subjectivities that voice it.

\section{The Critique of Capitalism}

In a number of works (Boltanski 2011; Boltanski and Chiapello 2005; Boltanski and Thevenot 2006), Boltanski and his colleagues lay an outline for a "sociology of critique", a concept which is an homage to "critical sociology" and a critique thereof. Critical sociology, from Karl Marx through the Frankfurt School to Jürgen Habermas, Axel Honneth and Nancy Fraser, has been characterised by conceptualising critique as a quasi-autonomous phenomenon in the social structure and social dynamics in two senses. First, critique is often seen as articulated at the margins of the social systems by relatively powerless actors; particularly in capitalist society, 'capitalist critique' is the domain of marginal (alas, elitist) groups in the academic and artistic fields, not a 
mainstream pastime. Second, in critical sociology critique is seen as relatively detached from social systems as it criticises the hegemonic structure ('capitalism', for example) as a whole. Identifying the sources of social pathologies in a single system - capitalism - means that overcoming them necessarily entails overcoming capitalism and establishing a new, non-capitalist society.

Boltanski sees both these characteristics as weaknesses of critical sociology. He seeks to preserve the notion of critique in sociology - and, to a large extent, revive it by giving it a redefinition that overcomes these weaknesses. First, Boltanski conceptualises the critique of capitalism as a normal, even quotidian component of social life in capitalism. Social actors living in capitalist, liberal democratic countries have the cognitive, institutional, legal, and social capacities to criticise the social system they inhabit. And indeed they do that all the time. Critique of capitalism is part and parcel of capitalism. Second, critique of capitalism does not necessarily entail a negation of capitalism as a totality, but may lay out a more nuanced critique of a certain mode of accumulation, or particular tenets therein. Critique of capitalism is not primarily a radical critique of capitalism as such but rather strives to make amendments to it. The sociology of critique that Boltanski professes treats capitalist critique as its object of research ("a social fact", in Durkheim's [1982] terms) and examines its status, function, and dynamics within the social system. Such sociology examines the role that capitalist critique plays in the way that capitalism is shaped and transformed. Indeed, Boltanski argues that transformations in capitalism are affected by its critique.

Hence, Boltanski turns critique from a highly theoretical, high-brow engagement to a popular social practice - local, contextualised, and quotidian. Such a definition allows us to think about workers' unionisation as a particular manifestation of the more abstract critique of capitalism, and hence as a vignette to examine how such critique is articulated today. An examination of the critical discourse that takes shape among hi-tech workers provides us with a snapshot of contemporary capitalism, a snapshot that points to the dynamism of capitalism, and to the critique to which it gives birth, a critique articulated in a significant social discourse, able to exert influence on capitalism. This is doubly true in the social and historical context at the centre of this article, i.e., the wave of unionisation in the hi-tech sector which hitherto almost completely lacked unionisation and was even antagonistic to it.

\subsection{Critique as an Inherent Part of Capitalism}

Capitalism is a social structure characterised by inherently unequal power relations. But these power relations are founded not on violence and coercion (except in the margins and in non-democratic regimes) but on an ideology of freedom and consent. It therefore requires a broad social legitimation. Boltanski understands legitimation as based on a hegemonic discursive act of justifications: capitalism is required to justify its oppressive and seemingly unjust facets. For example, the poverty and deprivation of a minority of the population might be justified as a by-product of a meritocratic ethos and of unequal distribution of resources that ultimately lead to a growth of social wealth and welfare, benefitting all.

This justification discourse cannot be understood merely as an ideology that veils power relations or allows their reproduction. Instead, it has a constructive facet as well: the justifications of capitalism also serve as tests for its critics. They can therefore be thought about as promises: capitalism promises a rise in social wealth, i.e., growth, personal freedom, and so forth. However, if it does not stand by its own promises, the rug may be pulled from under its feet and it becomes prone for critique. Critique, 
according to this premise, can be thought of as a constant examination of how successful capitalism is in living up to its promises.

According to Boltanski, this discourse, which oscillates between justifications and critique, lays the foundations for political transformations in capitalism, that is, transformations which are not determined by capitalist structure and dynamics. To the extent that capitalism fails to deliver on its own promises, and the critique of capitalism picks up steam, its mode of operation might be transformed. In an attempt to regain legitimation, capitalism might internalise the mounting critique against it and respond to it by its adaptation and transformation at a level that allows the forestalling of further critique. Hence, the dynamism of capitalism is a product not only of structural constraints, but also of its critique.

Boltanski, then, offers a theoretical model where the critique of capitalism is part and parcel of capitalist transformations. This does not contradict the Marxist idea that capitalist transformations are also the result of structural constraints, but rather highlights a political component that can explain the changing configuration of capitalist regimes. In that regard, Boltanski follows the thesis of Max Weber (1958) concerning the ramifications of Protestant ethics on the spirit of capitalism, and extends it from a theory that explains the rise of capitalism to one that explains its transformations ever since.

Critique of capitalism is articulated by myriad actors and in a plethora of sites, and has diverse manifestations: from critique on the cost of living and government regulation, to critique of monopolies and the super-rich. Notwithstanding its great diversity, Boltanski identifies two distinguishable central streams in the critique of capitalism: a social critique and an artistic critique. These have been, empirically, the two clusters of critique that have influenced the course of capitalist transformations, at least since the middle of the 19th century. The social critique protests the inequality, poverty, egoism, and greed that capitalism entails. The artistic critique protests the suppression of creativity, authenticity, and personal expression, and the inability for self-realisation, that prevail in capitalism.

With the distinction between social and artistic critique, Boltanski seems to follow to a large extent the analytical distinction offered by Marx (albeit without accepting its deeper theoretical ramifications): the social critique more or less parallels Marx's critique of the exploitation of one class of people by another, resulting in oppressive social relations, while the artistic critique parallels some aspects of the Marxist critique of alienation that workers are subjected to, which contributes to their de-humanisation. The former is commonly attributed to the Old Marx and is theorised, for example, in the first volume of Capital (Marx 1990). The latter is attributed to the Young Marx and is theorised, for example, in The Economic and Philosophical Manuscripts of 1844 (Marx 1988) (see also Callinicos 2006, 51-71).

Analytically, both clusters of critique are always present in capitalism. What's more, in Marxist thought, exploitation and alienation are mutually linked: they are both inherent to capitalism; one cannot be solved without the other; and overcoming them requires the overthrow of capitalist regime. However, the theoretical framework offered by Boltanski argues that, historically, capitalism is characterised by partially responding to these critiques; that is, not by substantively overcoming exploitation and alienation but by mitigating them, or diminishing some of their harmful ramifications.

\subsection{Historical Transformations in the Critique of Capitalism}

A peculiar historical dynamic exists between the two clusters of critique. Different eras in capitalism are characterised by the predominance of one type of critique over the 
other. This should not come as a surprise: different regimes of accumulation (Aglietta 2001) create different structural pressures and social distresses, and give rise to different kinds of critique. Hence, the response of capitalism to one type of critique entails the suppression and exclusion of the other. At a given time, then, and under a given capitalist regime, one type of critique waxes while the other wanes. This can be explained on three accounts.

First, even though the social critique and artistic critique can be seen as complimentary they are also contradictory, at least within the hegemonic liberal framework under which capitalism operates. Whereas the social critique is primarily social, protesting the harm of capitalism to social welfare, the artistic critique is primarily individual, protesting the harm of capitalism to personal welfare. In the framework of liberal thought the two critiques are set on a balancing scale, where one side carries "freedom to" and the other one carries "freedom from", in Berlin's famous formulation (Berlin 2002; see also Harvey 2005, 5-38).

Second, even though the spectrum of critique is varied, multiple, and obviously also contradictory - different people and different social groups can put forth contradictory critiques and demands - the fact is that in order to translate social indignation into a substantial and effective political action there is a need to galvanise protest energies around specific objectives; hence one critique surfaces as dominant.

Third, the dominant critique is directed towards the more significant hurt caused by the mode of accumulation that prevails at a given time. As we'll shortly see, such hurt also historically and empirically tends to move on the pendulum between hurting social welfare and hurting personal welfare.

These two clusters of critique, then, are set in a dialectic historical dynamism: the response of capitalism to one type of critique contributes to the shaping of a capitalist mode which subsumes and silences the other type of critique. This theoretical model could help us understand some of the deep transformations in capitalism of the last century and a half. The laissez-faire capitalism of the second half of the 19th century was characterised by an unprecedented rise in wealth, primarily thanks to the industrialisation of production. But wealth was highly concentrated. Inequality and poverty surged. Industrialisation also created unprecedented social problems: the move from agrarian villages and cottage industries to urban factories, and with it the breakdown of the extended family and the community (or gemeinschaft) as support systems, left workers more vulnerable to the flux of the market, which had become more volatile and crisis-ridden. Not only was the power of capital vis-à-vis labour growing under conditions of industrialisation and the centralisation of production, but the presence of the state in the economic sphere was minimal; the state mostly saw itself in a supporting role of enabling social actors to conduct their own affairs in that context. Workers therefore found themselves, in the second half of the 19th century, heavily exploited in an economy that became richer and more unequal, and were left to their own devices in a turbulent free market.

At that time, and in light of deep cyclical economic crises, the social critique grew stronger. Growing wider and deeper, the social critique - at a propitious time, when the threat to a collapse of the capitalist system as a whole seemed imminent - had ultimately brought about a reorganisation of the capitalist system and the formation of a new mode of accumulation, commonly dubbed Fordism, Welfarism, or Keynesian economics. Fordist capitalism was moulded by internalising and containing the social critique, alas measuredly and partially, by establishing mechanisms that restrained the total freedom of capital and the dominance of the free market in social affairs, the aim of which was to build a defence barrier between labour and a turbulent market, and 
increase equality (Piketty 2017): social insurance, wealth redistribution, greater governmental involvement in the economy, labour legislation, and the provision of social services. In Polanyi's terms, this has increased the embeddedness of the economy in society (2001).

Dialectically, responding to the social critique of capitalism enabled the thriving of capitalism in its Fordist constellation. For example, labour became more subordinated to a managerial echelon and to the rationale of the assembly line and an increasing division of labour that in turn led to a more alienated world of work (Braverman 1974). To a large extent, and because workers implicitly accepted the assumption that responding to the social critique is antithetical to a response to the artistic critique, workers under the Fordist regime accepted a growing measure of alienation as a necessary evil in return for a higher measure of mitigating exploitation. The ramification of responding to the social critique, then, has been the revoking of the artistic critique. For example, collective bargaining agreements prevented differential pay for the most qualified workers, i.e., held back a pure meritocratic principle. Work in the Fordist factory and office entailed a high degree of alienation: the character of work was dictated by an external authority, located higher in the organisation hierarchy (Noble 1984).

We stress the dialectic between the clusters of critique in order to underline the degree to which the capitalist formation that responded to the social critique (i.e., Fordism) became a catalyst for the rise in dominance of the artistic critique. Seedlings of the artistic critique of industrial, Fordist capitalism can be found in the 1936 Charlie Chaplin film Modern Times. Facing the tyranny of the assembly line in the first scene, the tramp feels alienated from the process of labour and its products, from other workers, and from himself. This scene has become one of the most iconic visual representations of the alienation of industrialisation. But recalling the following - much less iconic - scene from the movie, which focuses on labour struggles, would help us to balance the picture somewhat: it represents workers' struggles at the time, which focused primarily not on alienation but rather on exploitation. These were struggles for tenure, collective bargaining agreements, social insurances, paid vacations, and higher wages.

The roots of the artistic critique are anchored in the Bohemian circles of the 19th century who sought to expand the realm of authenticity, personal expression, creativity, and individualism under the weights of increasing modernisation, bureaucratisation, urbanisation and massification of social life. The more Fordist capitalism took hold and succeeded, the more it also seemed like a negation of the Bohemian vision. Both in the realm of work and the realm of consumption - which additionally became a central site for meaning and identity - standardisation, passivity, compartmentalisation, and hierarchy took hold. As a counter-movement to that, the artistic critique gained traction, protesting the grand centralised factories, the rigid hierarchy in the workplace, the strict division of labour and alienation from it, the bureaucratisation of the state, and its deep penetration into social life. An epitome of the tide of the artistic critique was the "1968 revolution' in Western capitalist democracies.

The capitalist formation that began to take shape in the following decades, the last three of the 20th century, was influenced to a large degree by the attempt to respond to the artistic critique and incorporate its demands. The recovery of capitalism from yet another structural cyclical crisis that befell it in the 1970s involved a restructuring of capitalism, and a formation of a new type of capitalism that promised to be less alienating, and to allow more personal expression and individualism in the world of work, and less hierarchy and oppression. This formation of capitalism was originally 
termed post-Fordism or the flexible regime of accumulation. Boltanski and others (most notably Castells [1996]) prefer to use the keyword "network" to characterise the spirit of contemporary capitalism. Network has become a legitimation term for a socioeconomic regime of a new kind that responds to the artistic critique. Network capitalism is characterised by a new conceptualisation of workers as autonomous nodes in the network. The most important quality of workers in the network economy is the ability to link up and connect with other nodes (workers, firms, projects) temporarily in order to carry out assignments. The network is seen as a flat, decentralised social sphere, comprised of multiple and overlapping ad-hoc and ever-changing assemblages (Fisher 2010).

To a large extent, hi-tech workers are the main protagonists of network capitalism (Fisher 2008). They are central carriers of the network ethos and culture, including elements such as flexibility, creativity, de-hierarchisation, meritocracy, and multitasking. By 'hi-tech workers' we refer to a social category with similar professional and employment characteristics: labour involving the production, management, and distribution of digital goods and services. Within the working class hi-tech workers are the prime beneficiaries of the promises of network capitalism. The promise of a world of work that allows greater personal expression, less alienation, more creativity and pleasure, autonomy and authenticity - promises emanating from the artistic critique resonate more fully among hi-tech workers, at least ideologically.

However, as aforementioned, the promise to mitigate alienation - regardless of the empirical question of whether this promise is realised, to what extent, and for whom is dialectically linked to an exacerbation of exploitation, or to a neglect of the social critique. Compared to Fordist capitalism, network capitalism is indeed characterised by deepening exploitation: an increase in inequality, the weakening of state mechanisms of redistribution and social protection, and a privatisation of economic life. From the point of view of hi-tech workers these transformations are manifested in a more precarious world of work (Standing 2016). The precariat class is subject to more flexible and unstable employment schemes and therefore suffers from employment insecurity and from difficulties in constructing a meaningful, linear career narrative (Sennett 2006; 2004). Hi-tech workers, in particular, are susceptible to an accelerated erosion in the value of their skills due to constant technological transformations, and are therefore especially vulnerable to ageism, a decreasing value of their labour with age. They are also more liable than other workers to over-work, and are less able to put off work to preserve their free time outside regular working hours.

The key ramification of the move to network capitalism, the justification of which is grounded on responding to the artistic critique and ignoring the social critique, has been the exacerbation of exploitation. Two central dimensions of exacerbated exploitation have been the commodification and privatisation of social life and an increase in inequality (Duménil and Lévy 2004). The first refers to the dwindling statist safety-net that protected individuals from the capitalist market: the reduction of insurances and public services, growing privatisation, and the liberalisation of local currencies. The second dimension (which is to a large degree a corollary of the first) refers to increasing inequality (Piketty 2017), or the upward redistribution of wealth (Duggan 2003). The new spirit of capitalism exacerbated exploitation. Given our story so far, it is little wonder that this capitalist regime gave rise to a growing social critique that became more vocal with rising rates of exploitation and at moments of crisis. One of the clear manifestations of the social critique was a series of global protests in 2011 that put forth demands for more equality, social solidarity, and statist oversight of the economy. 
Another articulation of the return of the social critique, we argue, is the emergence of unionisation attempts among hi-tech workers. As early as 1999 (when the French original of The New Spirit of Capitalism came out), Boltanski identifies the germination of a return of the social critique (Boltanski and Chiapello 2005, 345-418). Drawing on his hypothesis concerning the dynamics of critique, we seek to extend Boltanski's investigation and ponder, two decades later, the formation of capitalist critique at the present moment, following a few decades of a dominant artistic critique, and the reemergence of the social critique. We seek to identify and describe the texture of a new critical discourse (Hariman and Cintron 2015). We argue that the discourse about the unionisation of hi-tech workers in Israel in the last few years - workers who have been socialised into working life in light of the ethos and achievements of the artistic critique - echoes the new sounds of the social critique that protests the exploitation and insecurity they face.

The contradiction between the two clusters of critique, the social and the artistic, creates a new and interesting dynamic of protest discourse. The return of the social critique does not mean a walk down memory lane. This is not, in fact, a return to but a contemporary rendering of the social critique. We seek to understand the new texture of critique which draws on the two clusters of critique. If it is not a return to the social critique en bloc, could it be a selective adoption from the two clusters of critique, or perhaps a new synthesis?

We argue that in understanding the novelty of the critique of capitalism in the present moment we need to take into account the changing subjects upholding the critique: hi-tech workers. The analysis of interviews with unionisation leaders in seven leading firms in the hi-tech sector raises important insights concerning the return of the social critique, the tension created between itself and the artistic critique, and the attempt by unionisation workers to settle the two clusters of critique.

\section{Hi-tech Unionisation: A Historical Overview}

The discourse about unionisation we examine here is one of conscious and direct resistance to the prevailing structural conditions and the hegemonic discourse of contemporary network capitalism. This discourse is shaped by the attempt to challenge and change network capitalism, if only locally. Most immediately, the discourse about unionisation emerges as a reaction to a state of discontent on the part of workers. It functions on two levels. First, this discourse facilitates the mobilisation of workers into collective action by pointing to a private predicament (job insecurity, for example) as a corollary of structural conditions, i.e., a collective problem. Seen from a slightly different angle, it is a discourse that is meant to legitimise the act of critiquing the hegemonic system (be it 'capitalism', at the macro-social level, or 'the management of firm X', at the local level). The very articulation of an alternative workers' voice (Freeman, Boxall, and Haynes 2007) suggests divisions and friction of groups who do not share the same interests within the firm. Under an ideology that imagines the firm as family, or upholds a meritocratic ethos that repudiates power asymmetries within hi-tech companies (Kunda 1992), the very articulation of the discourse about unionisation is a contrarian act that requires legitimacy (Preminger 2018).

Second, the discourse about unionisation also functions as a platform over which concrete demands vis-à-vis the management are articulated. It is a discourse that lays out concrete problems and demands concrete solutions to amend them. Such demands tend to be bundled under a unified organising principle. Hence the discourse about unionisation also creates a general framework within which concrete demands are set, or from which they flow. We use the discourse about unionisation in the Israeli 
hi-tech sector to enquire how hi-tech workers put forth a new, combined model of critique of network capitalism, and how it reflects their unique positions, in that order.

Lacking natural resources and raw materials, Israel achieved competitive advantage in the global market by training and sustaining a highly qualified labour force, scientific centres, and research and development institutions, making the Israeli hi-tech sector industry world-renowned (Senor and Singer 2009). This happened at a phenomenal rate: in 1965, the hi-tech sector was responsible for $37 \%$ of Israel's industrial production. By 1985, this figure had grown to $58 \%$, and by 2006 to $70 \%$ (IMFA 2009).

Israel now has the highest concentration of engineers and the highest concentration of hi-tech companies per capita in the world: 5,900 companies in 2014 - one company for every 1,448 citizens (Hoffmann 2014). About 303,000 workers are currently employed in the industry, accounting for $9 \%$ of all Israeli employees (CBS 2017). Second only to the USA, Israel has more companies trading on NASDAQ than any other country, including India, China, Korea, Singapore, and Ireland. Most major global technology firms have research and development (R\&D) sites in Israel, among them Apple, IBM, Microsoft, PayPal, Amazon, Facebook, Google, Cisco, and Intel the last being the biggest private employer in Israel, with more than 10,000 employees (Rabat 2017). The Israeli hi-tech sector is also the fastest-growing industry in the nation. In 2006, it was growing by $8 \%$ annually, and $4.9 \%$ of Israel's GDP was spent on hi-tech R\&D (IMFA 2009). These levels of investment place Israel highest among OECD countries (Senor and Singer 2009). The Israeli hi-tech sector also offers one of the country's most desired positions in the labour market, with high salaries and generous benefits, flatter hierarchies, prestigious social status, and an environment that caters to the needs of its relatively young workforce. In late 2017, the average monthly salary for a software developer was NIS 26,644 (equivalent to 6,150 euros), more than 2.5 times the average salary in Israel (Manela 2017).

The 2008 global economic crisis, as well as harsher competition from emerging markets, led to lower profits in the Israeli hi-tech sector. In almost all the firms reviewed here, workers took a blow in their employment terms for the first time and witnessed re-organisation steps that resulted in mass lay-offs, the shut-down of R\&D centres, the outsourcing of labour, and the offshoring of whole divisions (Calcalist 2013). It was the first time that this generation of hi-tech workers had experienced such a blow, where even in flagship firms - jewels in the crown of the Israeli labour market where every young programmer hopes to work - employment terms were hurt. In this context of pay-cuts and lay-offs, unionisation started picking up steam.

Another context for unionisation in the hi-tech sector was a more general revitalisation of organised labour in Israel, powered by Israel's most prominent union, the Histadrut (a shorthand for the New General Federation of Workers). The Histadrut has around 700,000 members, accounting for $20 \%$ of the Israeli labour market (Bsoul 2017). In the Israeli industrial relations system, trade unions function as 'umbrella organisations' of which the largest and most prominent is the Histadrut. Unions affiliated with the umbrella bodies are represented in firms through work councils that negotiate with their employers collectively. Israeli labour law holds that a work council must be recognised if one-third of a company's employees joins it. Israel's first and largest hi-tech trade union, the Union of Cellular, Internet and Hi-Tech Workers, was established by the Histadrut in July 2014, following growing interest among ICT professionals to unionise. Within a short time, the new union garnered momentum and was able to unionise thousands of workers in these sectors. Six of the cases discussed here were unionised with this framework. In 2010, the Histadrut established the Trade 
Unions' Division, meant to support the establishment of work councils in the workplace (Shtauber 2017). The number of unionised workers grew by 100,000 workers between 2010 and 2016 (Bank of Israel 2013). The councils studied here should therefore be seen as a larger revitalisation of unionisation in the Israeli job market.

\section{A Case Study of Unionisation in the Israeli Hi-Tech Sector}

\subsection{Research Design and Methodology}

Research for this article is based on in-depth interviews with leaders of unionisation in seven hi-tech firms. They were conducted between November 2017 and January 2018. For the sake of privacy, we have not only kept the anonymity of interviewees but also made a disjuncture between their statements and the firms. We will therefore give a general profile of the interviewees. All interviewees were key figures in the unionisation efforts, and all cases refer to established firms. Each firm employs thousands to tens of thousands of workers worldwide (except one that employs merely hundreds). The peak capitalisation value of the firms is between $\$ 300$ million to $\$ 140$ billion.

The interviews lasted about two hours. Each interview was analysed in order to deduce the ways by which hi-tech workers articulate their critique of their workplace (and by extension, of capitalism at large) and their demands towards their employers. What interests us particularly are the conditions of possibility that workers assume when they come to articulate their demands: what is a legitimate demand and what is not? What demands will mobilise and unite or divide workers? We focus, then, on the interpretive universe of workers. The objective course of unionisation and the dynamics of negotiation will remain in the background (and are presented in Fisher and Fisher 2019a). The findings refer to both the discourse of critique and the discourse of the possibility of critique (a meta-discourse, if you will) of both unionisers and those who were sceptical and hesitant (as echoed in unionisers' discourse).

\subsection{Unionisation as Social Critique}

As aforementioned, the world of work for hi-tech workers is heavily influenced by the success of the artistic critique. In such an atmosphere, the social critique has become virtually silenced in the discourse of work. The first noteworthy finding, therefore, is the return in itself of the social critique to the discourse on work. In a sense, the mere demand to unionise is probably the most significant manifestation of that return. It entails a plea to treat every single worker as part of a group (or a social category) and demands collective rights.

In respect to the audacity of the act of unionisation in itself and the meaning that workers gave to it, we can best learn from the voices of workers who opposed the unionisation effort. We focus here on how the voices opposing unionisation were perceived and interpreted by union leaders, as the latter required them (and allowed them) to articulate their actions and the symbolic significance of their actions. For these workers particularly - and to a lesser degree, for most workers - the very act of unionisation was perceived as heresy, precisely because unionisation draws legitimacy from the social critique and demands a response to it. In all our cases, organisers faced opposition from workers, reflecting a rejection of the legitimacy of the social critique, or an affirmation of the artistic critique. Unionisation was seen as an antinomy to the work ethos of meritocracy and competitiveness and to flexible employment in the hi-tech sector.

A prominent reason for opposing unionisation prima facie was the negative image of organised labour among hi-tech workers, who do not see themselves as part of the 
'working class' at all. To them, unions are particularistic interest groups that take care of cronies at the expense of the general public and the public good. Many recoiled from the aggressive image of work councils. They perceived councils as violent, belligerent, and political, while perceiving themselves - people of science and reason - as abhorring such tactics. A unioniser tells of conversations he had with workers in order to encourage them to join the union:

Colleagues have told me "there's no way we are joining the Histadrut", since they perceive it as a corrupt organisation. People in hi-tech always shun the Histadrut, because of the notorious councils, such as the Ports Workers' union, or the union of the Electric Company. I needed to explain to representatives of the Histadrut that we are in hi-tech land, that in this case we need to act differently and use different tactics and a different language [in order to mobilise workers] ${ }^{1}$.

A member of another unionisation effort tried to shy away from identifying the current effort with classical workers' struggles as much as possible:

When I decided I want[ed] to establish a council I met with a lawyer and asked him to set up some type of a voluntary association so we can begin to organise [...] I did not want to ask my colleagues to join the Histadrut. Its socialist approach was not to our liking.

There was particular disdain for strikes. Whenever the possibility of shutting down the firm's offices came up, opposition was raised from workers who argued that hi-tech workers were not "thugs", and that they should solve their differences with management through negotiations.

Opposition was raised, then, not merely out of fear of possible negative consequences of the union's actions, but out of fear that management could perceive the very act of unionisation as heresy, a vote of no confidence in the firm. Underlying that was the idea that the firms would seek to please its workers at all costs. These workers accepted the corporate view that establishing a work council in the workplace was redundant as there was already a unit whose role it is to solve workers' problems: human resource departments. Given that view, some workers feared that establishing a work council would create a conflictual atmosphere.

Some workers voiced more ideological arguments for opposing unionisation that demarcate the social critique outside the legitimate discourse of work. They feared that establishing work councils would encourage mediocracy, since it would, according to their view, undercut management's ability to dismiss under-performing workers in order to improve the firm. They argued that work councils could undermine the value of excellence and the authority of management to evaluate it. They perceived councils as organisations that protected failing workers, and objected to this based on a radical meritocratic ethos that argues that talented workers do not need a union at all. Moreover, some saw unions as hindering the development and advancement of outstanding workers. Sharing this sentiment, the incipient councils sought to make sure that agreements would not encourage mediocracy. As one organiser told us:

According to the agreement we signed, if the firm decided that someone is not good enough and it wishes to fire them - it's their prerogative. The council does

\footnotetext{
${ }^{1}$ All quotations were translated from Hebrew by the present authors.
} 
not interfere in such cases. Hence the argument regarding encouraging mediocracy is simply not true. We interfere only when there are widespread organisational redundancies.

Another widespread concern of workers opposing unionisation was that unionisation could lead firms to discard the Israeli market for countries where organised labour is weak or non-existent, thus aggravating the distress in the hi-tech sector. A unioniser told us of his fellow workers "warning that if a work council is established the firm will leave Israel altogether". Unionisers tried to refute the likelihood of such predictions: "I used to tell them: the firm already has sites in France and Germany, where workers are expansive and unionised. Evidently these sites thrive, so such concern is unfounded".

\subsection{Expressions of the Social Critique among Unionisation Hi-tech Workers}

The legitimacy for unionisation is in and of itself, then, a manifestation of the social critique. But it is merely a precondition to express critique and lay out demands. Aspects of social critique were recurrent in interviews, were part of councils' demands, and even found their way into agreements. The central theme raised by workers, and that which was singled out as the prime motivation for their unionisation attempts, was an indignation against arbitrary redundancies, perceived by workers as part of an attempt by management to improve the firm's bottom line by reducing operating costs. According to workers, such measures do not arise from real business and the competitive needs of the firm, but from a faulty attempt by management to improve the financial image of the firm in the eyes of investors and shareholders. A leading unioniser explains the circumstances that led to the establishment of a union:

In 2014, a new global CEO stepped in, and immediately declared a $10 \%$ decrease in labour-power - an unprecedented measure in our firm. In Israel, this meant a redundancy of 80 workers. We had a $R \& D$ lab up north with 50 workers that was shut down. Workers received dismissal notifications on a Monday - by Wednesday the lab was shut down. In the central R\&D lab 30 workers were laid off. Some of them had been working in the company for over 20 years.

A worker at another firm, who was involved in unionisation efforts there, describes a similar measure of mass redundancies based not on meritocratic indicators, but as a means to improve profitability:

Three weeks after I joined the company as a team leader, I was instructed by my manager to comprise a list of $30 \%$ of my workers to be laid off. This recurred every few months. I was shocked to realise how many workers the firm fires. After a few months my manager informed me that the company is set to fire $80 \%$ of its employees in Israel over the next three years. This meant moving from a company of 1000 workers to only 200-250 workers. After only a few weeks, my manager called me up again, telling me the goal is now to do it over the course of one year rather than three. At this point I decided to put a stop to it and considered unionisation.

While these mass redundancies were taking place, the company continued handing out generous bonuses to its managers and owners. This made workers doubly frustrated and drove many to join the work council. 
Another recurring theme in many of the interviews was worker concern about management attempts to outsource projects as part of a grander scheme to dry up the Israeli site and increasingly move activity to cheaper sites. In some instances, workers were charged with mentoring foreign programmers and engineers while massive redundancies took place. After realising that these new workers were meant to replace Israeli workers with cheaper ones, they became more supportive of establishing a union and fighting to prevent the Israeli site from being dried up. Unionising workers, then, considered offshoring work to be an illegitimate means to cut costs, antithetical to the hi-tech ethos.

The unionising workers also detected a threat to their status from the growing number of 'subs' (shorthand for substitutes) - temporary workers hired through external human resource providers. These workers were being integrated along fulltimers while the latter were being laid off. Unionisers recognised that these subs "can be fired at will. The firm has zero commitment to them". Workers saw this kind of ad hoc employment scheme as a means to undermine the firm's commitment to its workers, and fought to keep the number of subs to a minimum.

A dominant reason for establishing councils was workers' demand for a higher degree of employment security - probably the crowning glory of the social critique. But they sought to articulate this demand in a way more fitting to the hi-tech sector. They did not ask for tenure. They demanded early retirement plans as an alternative to mass redundancies, schemes which assure economic and social support for redundant workers. These arguments reflecting the spirit of the social critique found their way to the negotiations and even the collective bargaining agreements (CBA). In two firms, where a CBA was signed, parties agreed on giving a longer notice period before dismissal, limiting the number of subs, and reducing mass redundancies by offering voluntary retirement plans. It is noteworthy that in all cases, wages and benefits did not take centre stage in the negotiations or the CBA. Hi-tech workers perceive their compensation to be high and inclusive of many material benefits as it is.

Workers were bothered primarily by the lack of employment stability and worked to come to an agreement about mechanisms that would allow workers slated to be fired reasonable time to find another job, as well as voluntary early retirement plans. The seeming contradiction between demanding stability and security on the one hand and accepting redundancies as a legitimate tool on the other hand is clarified by one of the unionisers:

I met up with a friend of mine who works for the Electric Company. When I told him that my firm can still fire workers at will if they are deemed not good enough, he said: "so, bottom line, your CBA doesn't protect workers". I replied that for us, in the hi-tech sector, when you are let go, you know you'll find another job. Now, after the CBA has been signed, every worker will be duly notified, and have seven months to find another job. Before having a work council, one could be fired from one day to the next. I find this development is a significant accomplishment.

\subsection{Manifestations of the Artistic Critique in the Demands of Unionising Hi-Tech Workers}

Outlining the demands associated with the social critique makes it clear that this is not a straightforward return to a long-gone world of work. Hi-tech unionisers do not follow the union's playbook of the 1950s. Not only do their demands pale in comparison to that era but also what we find particularly significant is their attempt to uphold these 
demands without conceding demands associated with the artistic critique. They seek to uphold the characteristics of the world of work which are the result of the artistic critique, such as calling into question the traditional divisions between managers and workers and between work time and free time; a commitment to meritocracy; and a dismissal of structural power relations in society.

This spirit goes hand in hand with only a partial adoption of the social critique. One of the unionisers summarises this succinctly:

Our struggle against management was persistent and strong, with many disputes and overnight negotiations, but it was always measured. Workers were quite reasoned and sympathetic to management's requests. We didn't want to do anything that would damage the firm. When at times we did use forceful tactics, it was always measured.

There was an overwhelming agreement among workers that dismissing lowperforming workers is legitimate and even necessary. Workers wholeheartedly adopted the competitive and performance-based discourse that characterises the hitech sector, but they also demanded that employers put in place mechanisms to help under-performing workers to improve and keep their jobs.

It is precisely the adoption of the point of view of managers that led workers to criticise management vehemently when the targets of dismissals - a measure they didn't object to in principle - were outstanding workers, and the measures taken were for pure financial or organisational calculus. In accordance with the meritocratic ethos characterising this sector, dismissing outstanding workers, who were seen as key to the firm's success and sustainability, as well as mass redundancies across all the firm's units, were strongly opposed and led many workers to unionise.

The opposition to dismissing good workers partly stems from the workers' view that this would hurt the firm and impair its development. Such critique adopts the business viewpoint, indicating the extent to which workers identify with the firm and assume an obligation and a right to be concerned with its well-being. A unioniser working at midmanagement level describes his personal experiences:

At that stage, after a few waves of redundancies, there were only outstanding workers left in the firm. And then another wave came, and as team leader you are told "choose the less outstanding workers out of the cadre of already excellent workers, and fire them'. That's how you ruin a firm. You lose your skills and knowledge that go off with the people you send home, and which may later be working for your competition.

The widespread criticism of management by workers was directed towards their failing professional performance during crises. But one can discern two underlying types of critique, concerning a failure of professionalism and a failure of recognition. These go hand in hand with the social critique and the artistic critique, respectively. The professional critique of workers states that while managers might be experts in business management, they are deficient in understanding the technological field, therefore taking faulty decisions concerning product development and the running of professional divisions. These faulty decisions have detrimental consequences for workers, leading to dismissals, and even putting in jeopardy the future well-being of the firm by undermining its competitive edge: 
Six or seven years ago we started noting a decrease in the firm's activity and profitability. It was evident that this was the result of a not-very-bright management - acquisitions that turned out to be a mistake, and executives taking large bonuses for themselves while the firm was not doing well. No one was taking care of the immediate future and how to defend the firm from collapse. The international management argued that redundant labour-power is the cause for losses, but in fact they were using this excuse to cover up their losses and their faulty decisions.

The crux of the other type of critique, concerning a failure of recognition on the part of management, is a misrecognition in the skills and professional abilities of workers, and the fact that their views and ideas are not taken seriously. A unioniser succinctly explains:

Why do people ultimately join the union? They are intelligent people, some are literally geniuses, but nobody treats them as such. There's no transparency, decisions are landed on us from above, and these workers approach their managers and say "look, I have an opinion regarding your decisions, I see things differently and I have ideas", but the management tells them their views don't count. That is the main reason why people have joined [the union].

This critique very clearly belongs to the artistic critique that demands a less hierarchical work organisation, where decision-making processes are based more firmly on meritocratic values and less on the structural position of power in the organisation. Ownership rights do cancel out, according to workers, other 'rights' that workers have in the firm, such as the right to be a part of it, and part of its success.

When workers tried to offer alternative measures to those of the management that might improve the state of the firm and prevent unnecessary cutbacks, they soon found that the management was uninterested in learning about their ideas. The insult was aggravated in light of workers' conviction that since they were the ones developing the firm's products, they were the only ones who could come up with appropriate solutions to the problems at hand. "You need to understand", a worker told us,

We are programmers. We are writing the code. We built the firm with our brains and our heart. It [selling code products] is nothing like selling washing machines. The well-being of the firm is wholly dependent on its workers and their expertise.

The two types of critique express a unitary view: workers feel they are more competent to deal with the problems facing the firm, and management is ill-equipped to understand the hi-tech market, its special needs and difficulties. The fact, therefore, that executives are unwilling to incorporate the professional views of workers into their decisions constitute a problem of both professionalism and recognition. One organiser told of a case in his firm:

Workers submitted a proposal for a development and improvement plan for the firm's products, with relatively low costs - but they did not receive any reaction from the CEO. Nobody refereed or reacted to our offer. So we started realising that something is not going well [...] thus we started realising we should be unionising. 


\section{Discussion}

The demands of unionising hi-tech workers in Israel in the last few years stem from both the social critique and the artistic critique. In addition to distresses and demands pertaining to the social critique, such as concerns about being laid off, and deteriorating contract terms and job stability - common concerns among workers in many sectors unionising hi-tech workers also raised concerns and demands pertaining to the artistic critique, pertaining to autonomy, recognition, and self-actualisation. Thus, workers asked that their professional expertise in the field and their deep knowledge of the hitech industry should be taken more seriously into account as far as strategic decisions regarding the future of the firm were concerned. Such a demand challenges the legitimacy of management to be the final decider, thus putting into question the organisational hierarchy. Unionising hi-tech workers perceive themselves as partners in the firm more than as its workers, and they seek organisational power to allow them to prevent their executives from advancing steps that will damage the firms, for example, by preventing the firing of outstanding workers in the name of efficiency.

However, what is surprising is not the articulation of the artistic critique among hitech workers, but rather the return of the social critique into the discourse on work, and its integration into a new position that refers to both bodies of critique. The return of the social critique is manifested through three central demands. The first is the demand to unionise in itself. In some respects, this is a meta-demand, a pre-condition to voice the social critique. It is therefore also a performative demand: it seeks to resurrect workers' rights to assert themselves as a collective and unionise in order to mobilise power and struggle for rights collectively. As we have seen, workers were well aware of the performative facet of their action, i.e., the fact that mere unionisation already constitutes a meaningful oppositional act, as if they were asked to cross the Rubicon from a purely artistic position towards the social critique.

The second demand associated with the social critique put forth by workers was that management would refrain from mass redundancies aimed at downsizing. Workers identified such a measure as stemming not from an operational need but as a means to increase the value of the stock, or to substitute existing workers with cheaper ones. Such a critique is meant not merely to protect workers as individuals but signifies the self-identification of workers as part of a class that is threatened by temporary substitute workers from other countries.

The third demand stemming from the social critique is that workers should have a voice and actual decision power on issues that were traditionally seen under the purview of management, but which have a direct ramification on the well-being of the firm and hence also on workers. While this demand is also anchored in the artistic critique - as it also protests the misrecognition of the talent and skills of hi-tech workers, and their central role in the success of the firm - it is nevertheless essentially a demand that seeks to change the structure of decision-making to allow workers to defend their workplace.

The pendulum of critique that Boltanski has so beautifully theorised, then, takes place within a concrete social constellation. Critique is articulated and voiced - and hence influenced - by particular social actors, with their unique position, ethos, habitus, and culture in capitalism. Hi-tech workers are in a unique position - a relatively small fraction but an elite, very unlike the factory workers of Fordist capitalism who were key agents in upholding the social critique in the first half of the 20th century. The argument that both autonomy (artistic critique) and security (social critique) are important is not in and of itself new. It has been made quite frequently in the context of cultural work and the creative industries (Oakley 2009; McRobbie 2016, 60-86). From this 
perspective, this article may be seen as evidence for the spread of this discourse from the frontiers of contemporary capitalism to the mainland.

The return of the social critique to capitalist discourse and its articulation by hi-tech workers does not mean the displacement and annulment of the artistic critique. As aforementioned, the social critique stands, to a large extent, in contradiction to the artistic critique, and responding to the one means ignoring the other. Unionising hi-tech workers, however, try to hold both ends of the stick: to resurrect the social critique while preserving the accomplishments of the artistic critique, of which they are the prime beneficiaries.

The re-articulation of the social critique creates a new and interesting dynamic in the discourse of unionising hi-tech workers. The contradiction between the two types of critique that requires a trade-off between them to be overcome puts forward a challenge that the unionising workers must grapple with: can capitalism be shaped in a way that responds to both the social critique and the artistic critique? Can the contradictory tendencies of these two clusters of critique be overcome? As this article has shown, unionising hi-tech workers choose not to go back to the old discourse of social critique and refrain from a dogmatic revision of old concepts and old tools. Instead, they try to articulate a contrarian position that draws also on the artistic critique, the fruits of which they cherish.

To fully appreciate the significance of the unique texture of critique that is articulated in the hi-tech sector, we must recall the special location of these workers vis-à-vis other workers, and vis-à-vis contemporary capitalism in general. The hi-tech workers at the centre of this research are among the most powerful within the broad field of digital labour in the most powerful and most profitable firms. Within the working class, they are the obvious big winners of the new digital economy, enjoying high pay, high status, and relatively stable employment arrangements. If anyone even comes close to the most hyperbolic promises of digital labour, it is them. It is their privileged positions that both allows them to 'rock the boat' and demand a change to the status quo, but also limits their demands so as to make sure the boat stays afloat. They are working very much within the framework of neoliberalism, accepting, as we have seen, its fundamental premises. But within this limited scope, and limited aspirations for social transformation, may also arise a new language which revives the legitimacy of the social critique and which other, much more vulnerable, less powerful workers in the digital sectors may pick up.

\section{References}

Aglietta, Michel. 2001. A Theory of Capitalist Regulation: The US Experience. New York: Verso.

Bank of Israel. 2013. Workers' unionizing in the Israeli economy: Overview for 2012. https://www.boi.org.il/he/Research/DocLib3/5-136-1.pdf

Berlin, Isaiah. 2002. Liberty: Four Essays on Liberty. Oxford: Oxford University Press.

Boltanski, Luc. 2011. On Critique : A Sociology of Emancipation. Cambridge: Polity.

Boltanski, Luc and Ève Chiapello. 2005. The New Spirit of Capitalism. London: Verso.

Boltanski, Luc and Laurent Thevenot. 2006. On Justification: Economies of Worth. Princeton: Princeton University Press.

Braverman, Harry. 1974. Labour and Monopoly Capital: The Degradation of Work in the Twentieth Century. New York: Monthly Review Press.

Bsoul, Janan. 2017. Israeli Workers Uniting in Masses? The Numbers Tell a Different Story. Haaretz, February 12.

Calcalist. 2013. Labour Market Shrinkage: Dismissals, Cuts and Freezing New

Requirements. Calcalist, October 28. 
Callinicos, Alex. 2006. The Resources of Critique. Cambridge: Polity Press.

Castells, Manuel. 1996. The Rise of the Network Society: Volume I: The Information Age: Economy, Society, and Culture. Oxford: Blackwell Publishers.

CBS. 2017. Labour Force Survey Data, 4th Quarter and Annual Data for 2017.

de Peuter, Greg, and Nicole Cohen. 2015. Emerging Labour Politics in Creative Industries. In The Routledge Companion to the Cultural Industries, edited by Kate Oakley and Justin O'Connor, 305-318. London: Routledge.

Duggan, Lisa. 2003. The Twilight of Equality? Neoliberalism, Cultural Politics, and the Attack on Democracy. Boston, MA: Beacon Press.

Duménil, Gérard and Dominique Lévy. 2004. Neoliberal Income Trends: Wealth, Class and Ownership in the USA. New Left Review 30: 105-133.

Durkheim, Emile. 1982. The Rules of Sociological Method. Vol. 38. Chicago: University of Chicago Press.

Fisher, Eran. 2008. The Classless Workplace: The Digerati and the New Spirit of Technocapitalism. Working USA: The Journal of Labor and Society 11 (2): 181-198.

Fisher, Eran. 2010. Contemporary Technology Discourse and the Legitimation of Capitalism. European Journal of Social Theory, 13(2): 229-52.

Fisher, Ben, and Eran Fisher. 2019a. When Push Comes to Shove: Dynamics of Unionizing in the Israeli High-Tech Sector. Work Organisation, Labour \& Globalization 13 (2): 37-56.

Freeman, Richard, Peter F. Boxall, and Peter Haynes. 2007. What Workers Say: Employee Voice in the Anglo-American Workplace. Ithaca, NY: ILR Press/Cornell University Press.

Hariman, Robert and Ralph Cintron. 2015. Culture, Catastrophe, and Rhetoric: The Texture of Political Action. New York: Berghahn Books.

Harvey, David. 2005. A Brief History of Neoliberalism. Oxford: Oxford University Press.

Hoffmann, Tzachi. 2014. Hi-Tech in Israel: 269,000 Workers, 5,900 Companies. Globes, July 29.

IMFA. 2009. ECONOMY: Sectors of the Israeli Economy, Israeli Ministry for Foreign Affairs. Accessed March 2, 2019. http://mfa.gov.il/MFA/Aboutlsrael/Economy/Pages/ECONOMYSectors of the Economy.aspx

Kunda, Gideon. 1992. Engineering Culture: Control and Commitment in a High-Tech Corporation. Philadelphia: Temple University Press.

Mackenzie, Adrian and Theodore Vurdubakis. 2011. Code and Codings in Crisis: Signification, Performativity and Excess. Theory, Culture and Society 28 (6): 3-23.

Manela, Maayan. 2017. In Hi-Tech - a 7\% Increase in Wages - 26,664 NIS per Month. Calcalist, January 24.

Marx, Karl. 1990. Capital Volume 1. New York: Penguin Classics.

Marx, Karl. 1988. The Economic and Philosophical Manuscripts of 1844. New York: Prometheus Books.

McRobbie, Angela. 2016. Be Creative: Making a Living in the New Culture Industries. Cambridge: Polity.

Noble, David. 1984. Forces of Production: A Social History of Industrial Automation. New York: Knopf.

Oakley, Kate. 2009. From Bohemia to Britart - Art Students over 50 Years. Cultural Trends 18 (4): 281-294.

Piketty, Thomas. 2017. Capital in the Twenty First Century. Cambridge, MA: Harvard University Press.

Polanyi, Karl. 2001. The Great Transformation: The Political and Economic Origins of Our Time. Boston, MA: Beacon Press.

Preminger, Jonathan. 2018. Israel's Recent Unionising Drives: The Broader Social Context. Israel Studies Review 33 (1): 23-41.

Rabat, Hagar. 2017. Intel Israel CEO: We Will Recruit 1,500 More Employees. Calcalist, July 20. 
Schiavone, Michael. 2008. Unions in Crisis: The Future of Organised Labour in America. London: Praeger.

Sennett, Richard. 2006. The Culture of the New Capitalism. New Haven: Yale University Press.

Sennett, Richard. 2004. Respect in a World of Inequality. New York: W. W. Norton \& Company.

Senor, Dan and Saul Singer. 2009. Start-up Nation: The Story of Israel's Economic Miracle. New York: Twelve.

Shtauber, Shuki. 2017. The Fight for the Council: Unionizing in the 2000s. Self-published.

Standing, Guy. 2016. The Precariat: The New Dangerous Class. London: Bloomsbury.

Weber, Max. 1958. The Protestant Ethic and the Spirit of Capitalism. New York: Scribners.

\section{About the Authors}

\section{Eran Fisher}

Dr. Eran Fisher is a Senior Lecturer at the Department of Sociology, Political Science, and Communication at the Open University of Israel. His books include Media and New Capitalism in the Digital Age (Palgrave, 2010), Internet and Emotions (Routledge, 2014, co-edited with Tova Benski), and Reconsidering Value and Labour in the Digital Age (Palgrave, 2015, coedited with Christian Fuchs).

\section{Ben Fisher}

Ben Fisher is an independent researcher, a graduate of the Global Labour University at the University of Kassel and HWR-Berlin, Germany. He studies mobilization patterns and trends among workers of the global ICT industry. 